\title{
Nanoporous PdCo Catalyst for Microfuel Cells: Electrodeposition and Dealloying
}

\author{
Satoshi Tominaka ${ }^{1}$ and Tetsuya Osaka ${ }^{2}$ \\ ${ }^{1}$ International Center for Materials Nanoarchitectonics, National Institute for Materials Science, \\ Ibaraki 305-0044, Japan \\ ${ }^{2}$ Nano-Science and Engineering, Applied Chemistry, Graduate School of Advanced Science and Engineering, \\ Waseda University, Tokyo 169-8555, Japan \\ Correspondence should be addressed to Satoshi Tominaka, tominaka.satoshi@nims.go.jp
}

Received 5 May 2011; Accepted 17 June 2011

Academic Editor: Milan M. Jaksic

Copyright ( $\odot 2011$ S. Tominaka and T. Osaka. This is an open access article distributed under the Creative Commons Attribution License, which permits unrestricted use, distribution, and reproduction in any medium, provided the original work is properly cited.

PdCo alloy is a promising catalyst for oxygen reduction reaction of direct methanol fuel cells because of its high activity and the tolerance to methanol. We have applied this catalyst in order to realize on-chip fuel cell which is a membraneless design. The novel design made the fuel cells to be flexible and integratable with other microdevices. Here, we summarize our recent research on the synthesis of nanostructured PdCo catalyst by electrochemical methods, which enable us to deposit the alloy onto microelectrodes of the on-chip fuel cells. First, the electrodeposition of PdCo is discussed in detail, and then, dealloying for introducing nanopores into the electrodeposits is described. Finally, electrochemical response and activities are fully discussed.

\section{Introduction}

Recent progress in microelectrochemical devices, for example, on-chip fuel cells [1-6], microbatteries $[7,8]$, and onchip sensors $[9,10]$, inevitably requires developments of both electrode materials with a large surface area and processes for depositing such materials precisely onto the tiny current collectors. For such selective deposition, we regard that electrodeposition is attractive, because this technique enables us to selectively synthesize metals onto conductive materials, even onto microelectrodes and to directly synthesize alloys without thermal treatment [11-13]. Moreover, its possible control of morphology by tuning applied current densities appears applicable to the synthesis of nanostructured materials [12-14]. Thus, electrodeposition is an important technique for synthesizing electrode materials for microelectrochemical devices. In view of this, we electrodeposited electrocatalysts for on-chip fuel cells, for example, Pt black, PtRu alloy, and PdCo alloy $[1,2,11,15]$.

In order to increase surface area of electrode of interest, nanostructured materials, for example, nanoparticles, have been widely used. Moreover, since each of the devices needs electrode with a different porosity appropriate to its own requirements for reactant and product transportations, synthesis of nanoporous structures with defined porosity is beneficial. For example, nanoporous Pt electrodes synthesized using soft or hard templates [16-19]. Though such templating processes are useful for synthesizing wellorganized nano- and microstructures, they are generally time consuming and need hazardous chemicals to remove the templates. Therefore, we considered that more versatile methods for synthesizing nanostructured electrodes for microelectrochemical devices need to be developed.

Contrary to such templating methods, the dealloying method can form metals with sponge-like nanoporous structures without any templates $[20,21]$. Dealloying refers to the selective dissolution of one or more components out of an alloy. The unique porous structure is formed by a competition of two processes: dissolution of less-noble component (i.e., pore formation) and surface diffusion of more noble component to aggregate into two-dimensional clusters (i.e., surface passivation) [20-24]. Their surface area can reach a value comparable to those of nanoparticles when the pore size is a nanoscale [25]. 


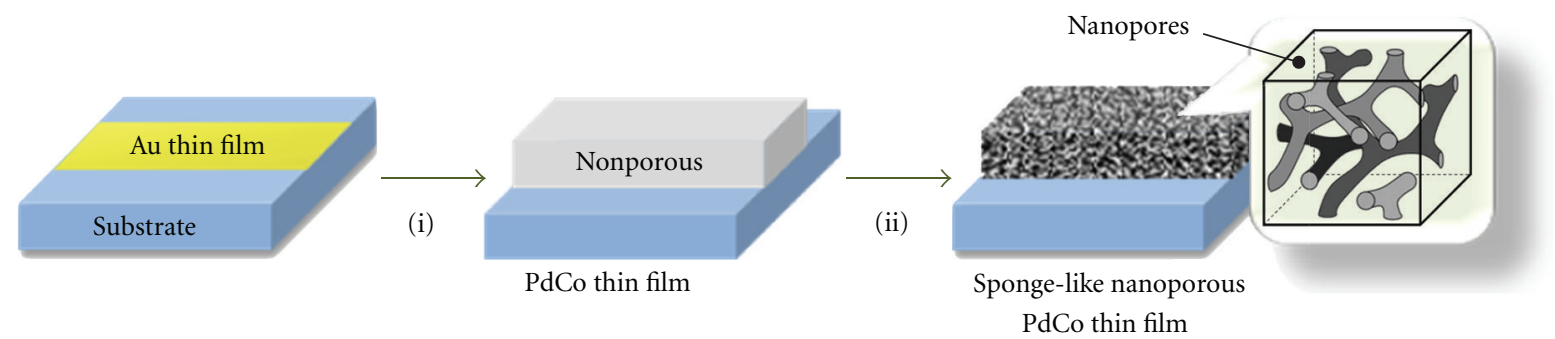

(a)

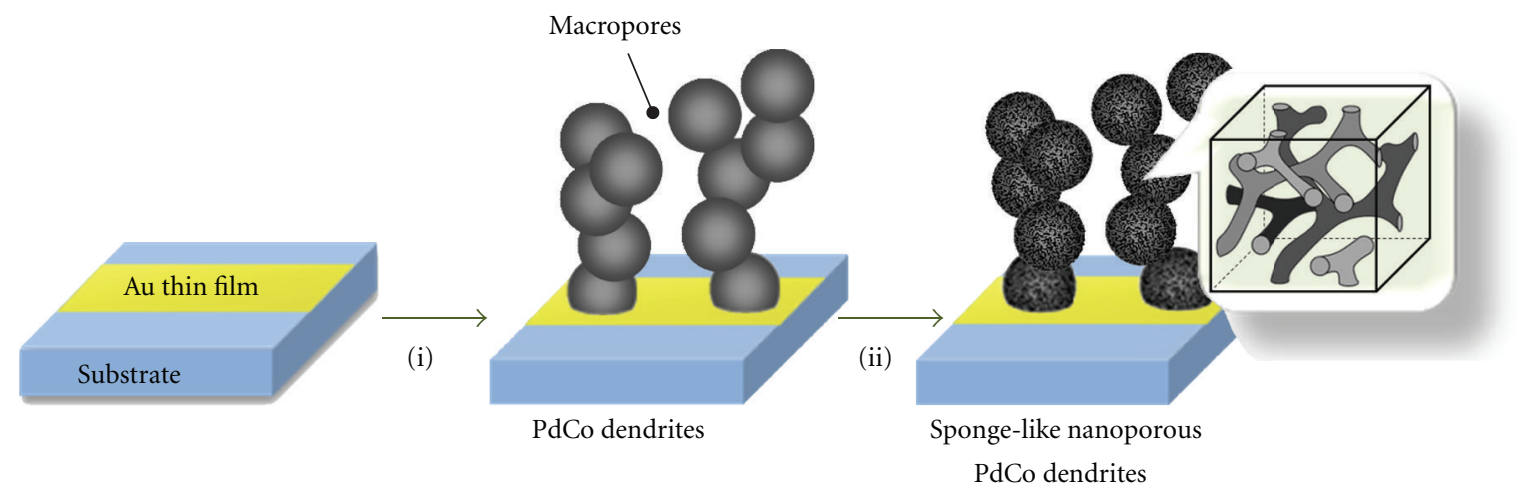

(b)

Figure 1: Electrochemical synthesis of nanostructured PdCo catalyst selectively on Au layer by (i) electrodeposition and (ii) dealloying. (a) Sponge-like nanoporous thin film and (b) nanoporous dendrites. Such three-dimensional porosity is beneficial in terms of diffusion inside.

Here, we summarize our recent research on the synthesis of nanostructured PdCo catalyst by electrochemical methods, which enable us to deposit the alloy onto microelectrodes of the on-chip fuel cells [1]. We have used the combination of electrodeposition and dealloying in order to synthesize sponge-like nanoporous thin films [26-28] and coral-reef-like nanostructures [29] selectively onto current collectors as illustrated in Figure 1.

Pd-based alloys such as PdCo are attractive as oxygen reduction reaction (ORR) catalysts for direct methanol fuel cells (DMFCs) because of its high activity comparable to Pt catalyst and its high tolerance to methanol [30-35]. Based on the latter property, we have used this catalyst for realizing a tiny on-chip DMFC of a membraneless design [1]. Since Pdbased catalyst may not be sufficiently stable in acidic media at such a positive potential for oxygen reduction reaction for practical use [36], we have tested the use of neutral $\mathrm{pH}$ atmosphere for the on-chip fuel cell system $[1,3]$. For the reasonable comparison with data reported by others, we used sulfuric acid as the supporting electrolyte for evaluating catalytic activity in this paper.

Figure 2 is a phase diagram of PdCo alloy with an indication of composition range enhancing ORR $\left(\mathrm{Pd}_{x} \mathrm{Co}_{1-x}\right.$, $x=0.7-0.9)[30-35,37-41]$. This alloy system mainly forms solid solution phase, but in some composition range, ordered phases of intermetallic compounds such as $\mathrm{L}_{2}$ phase (i.e., $\mathrm{Pd}_{3} \mathrm{Co}_{1}$ ) and $\mathrm{L}_{0}$ phase (i.e., $\mathrm{Pd}_{1} \mathrm{Co}_{1}$ ) can be formed $[42,43]$. In the potential range where high ORR activities were obtained, $\mathrm{L}_{2}$ type $\mathrm{Pd}_{3} \mathrm{Co}_{1}$ phase may exist. Since those

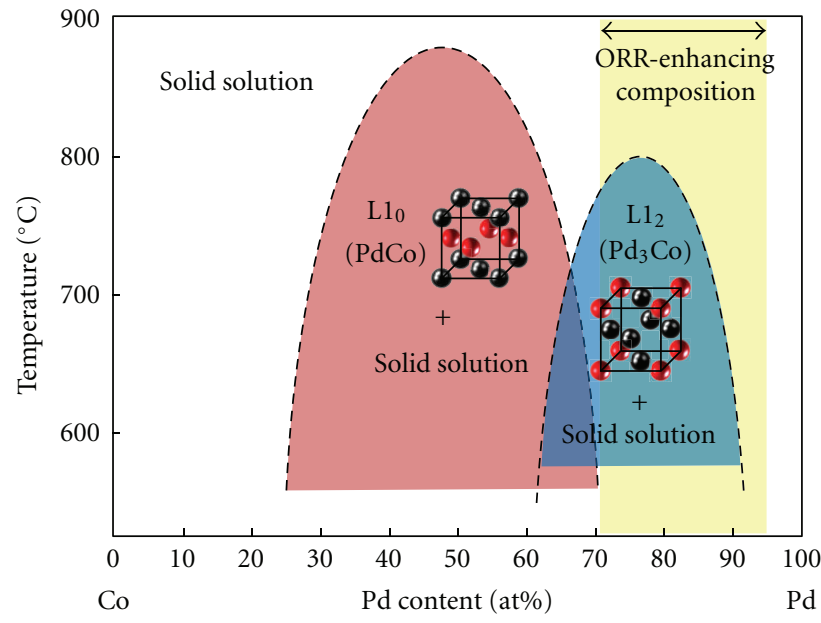

FIGURe 2: Phase diagram of PdCo system showing the composition range where oxygen reduction reaction is enhanced. The diagram was based on the figure reported in the literature [43]. Mainly, the phase is an fcc solid solution. In specific composition range, the alloy contains ordered fcc phase ( $\mathrm{Ll}_{2}$ type) or ordered face-centered tetragonal phase ( $\mathrm{L}_{0}$ type).

ordered phases were detectable only by electron diffraction, we have to be careful on such. The surface composition was reported to be Pd-rich after reduction in $\mathrm{H}_{2}$ and Co-rich after oxidation. This surface segregation is typical for this 


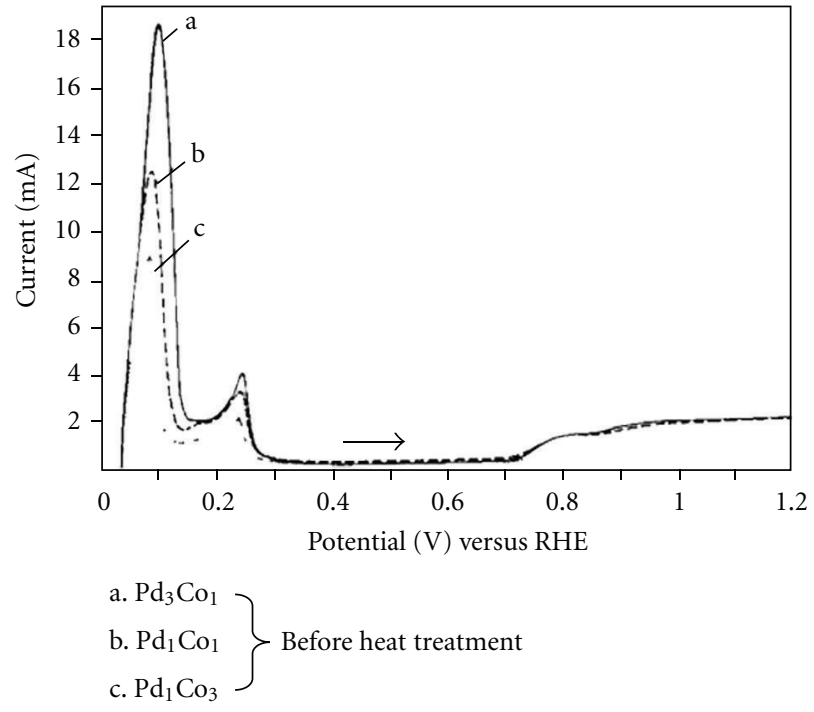

(a)

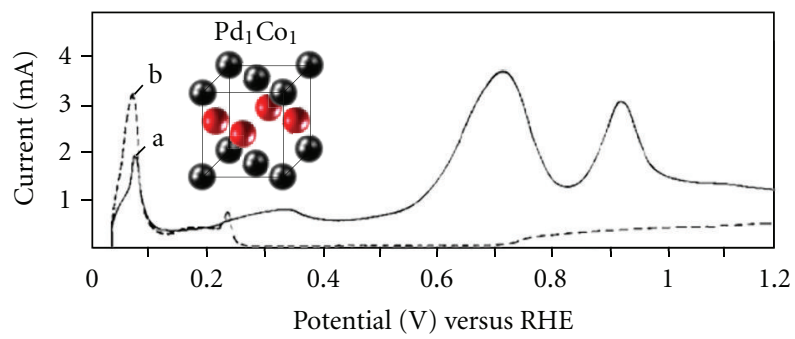

a. 1st scan

b. 2nd scan

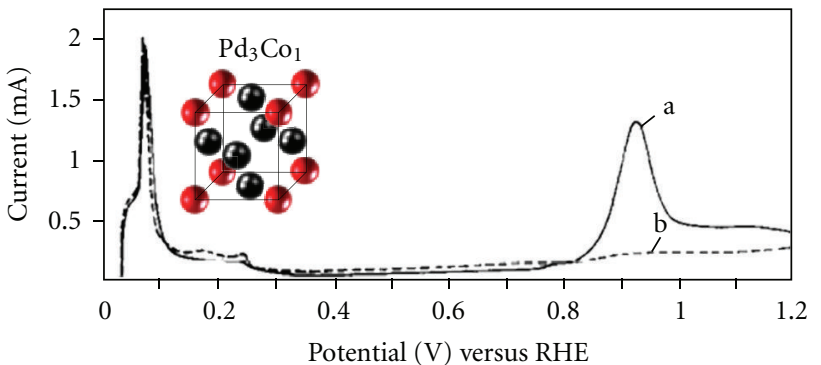

a. 1st scan

b. 2nd scan

(b)

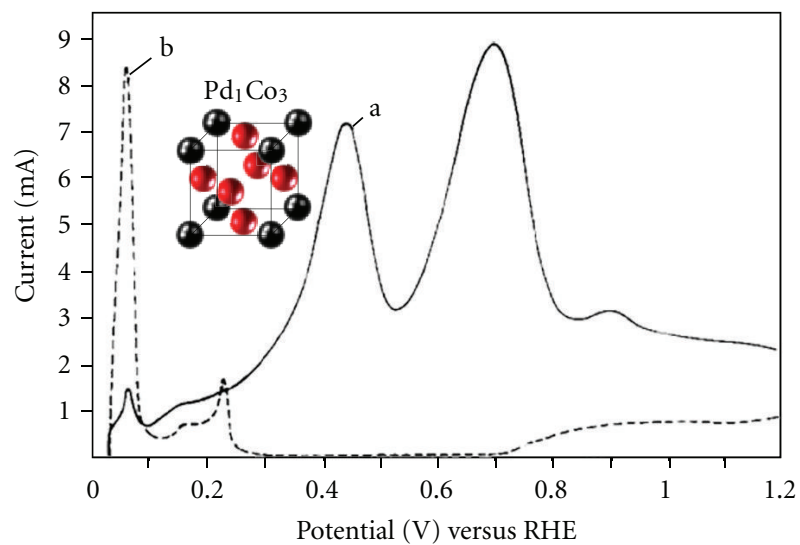

a. 1st scan

b. 2nd scan

(c)

(d)

Figure 3: Linear seep voltammograms of PdCo powders (positive scans) in nitrogen-saturated $0.5 \mathrm{M}$ sulfuric acid solution: (a) Before heat treatment: Curve (a) $\mathrm{Pd}_{3} \mathrm{Co}_{1}$, curve (b) $\mathrm{Pd}_{1} \mathrm{Co}_{1}$, and curve (c) $\mathrm{Pd}_{1} \mathrm{Co}_{3}$. (b-d) After heat treatment at 500 ${ }^{\circ} \mathrm{C}$ : Curve (a) first sweep and curve (b) second sweep after reduction with hydrogen. Reproduced with permission from [42]. Copyright 1986, Elsevier.

type of alloys as supported by the alloy segregation theory [44].

In order to use PdCo catalyst for fuel cells, understanding of electrochemistry is needed. Mallet et al. reported linear sweep voltammograms of PdCo alloys scanned in acidic solution [42]. Figure 3(a) shows that the disordered phases did not exhibit any anodic current associated with Co dissolution, but this does not mean high stability of them, because the authors reported that these samples lost some portion of Co atoms just after dipping into the solution. It is reasonable that the redox potential of Co is more negative than the hydrogen evolution potential in the acid solution.
The removal of Co atoms probably resulted in the formation of a passive Pd layer.

Since, from the viewpoint of thermodynamics, Co atoms in the ordered phases are considered more stable than those in disordered phases, the Pd-rich ordered phases of $\mathrm{L}_{2}$ type are considered the most stable in acidic media. Anodic current attributable to Co dissolution was observed for an ordered phase of $\mathrm{Pd}_{3} \mathrm{Co}_{1}$ above $\sim 0.8 \mathrm{~V}$, which is more negative than fuel cell cathode potential. This result indicates the stability may not be sufficient even for this phase. Considering that the charge associated with the dissolution was roughly in the same level as oxide formation current and 
that such dissolution was observed only in the first scan, only the surface Co atoms were considered to be dissolved. The same thing holds true for the other ordered phases. These results indicate that the surface of PdCo alloys is stabilized in the fuel cell condition by the formation of Pd skin layer.

\section{Synthesis of PdCo Alloys by Electrodeposition}

Electrodeposition of PdCo alloys was investigated by Abys et al. [45], and their aqueous bath was in a mixed ligand system. The first ligand, that is, ammonia, forms strong complexes with palladium and weak complexes with cobalt. The second ligand, that is, an organic molecule containing carboxylic acid group(s), forms strong complexes with cobalt, because cobalt complexes (octahedral with coordination number 6 [46]) bind favorably to oxygen containing ligands rather than to nitrogen containing ligands. These complex formations bring the deposition potentials of $\mathrm{Pd}$ and Co closer. Moreover, $\mathrm{pH}$ control of the solution $(<10.58)$ is important to obtain a stable bath. They investigated numerous ligands consisting of mono-, di-, and tetracarboxylic acid.

Figure 4 shows typical scanning electron microscope images of PdCo alloy synthesized by electrodeposition. By applying a low current density, a flat film with granular surface with ca. 10-nm particles was obtained (Figure 4(a)), while dendritic deposits with ca. 50-nm particles were obtained by applying a high current density (Figure 4(b)). The pores between dendritic deposits were expected to make the entire surface readily accessible by the reactants. The deposition condition and the solution were adjusted to obtain active catalyst for ORR (details are available in Section 6) [11]. The particle size is quite large compared to that of typical fuel cell catalysts, that is, $<10 \mathrm{~nm}$, reasonably leading to the conclusion that further improvement in nanostructure is needed for fuel cell applications. Thus, the surface was modified with additional PdCo deposits with smaller particles, which were deposited at a similar condition as the flat PdCo film. As shown in Figure 4(c), the surface of the dendrites was successfully covered with small particles in the $5-10 \mathrm{~nm}$ range. This treatment increased the surface area by ca. $30 \%$ as summarized in Table 1 .

The dendritic one was a substitutional solid solution of $\mathrm{Pd}_{75} \mathrm{Co}_{25}$, which is in the composition range active in the ORR [11] (cf. Figure 2). The X-ray photoelectron spectroscopy (XPS) results (Figure 5) indicate that the surface $\mathrm{Pd}$ and Co were metallic, not oxide, by comparing the binding energies of the deposits $\left(\operatorname{Pd} 3 d_{5 / 2}: 334.7 \mathrm{eV}\right.$, Co $2 p_{3 / 2}$ : $777.4 \mathrm{eV}$ ) to those of a metallic $\mathrm{Pd}$ and a metallic Co reported in the literature $\left(\mathrm{Pd} 3 d_{5 / 2}: 335.1 \mathrm{eV}\right.$, Co $\left.2 p_{3 / 2}: 778.3 \mathrm{eV}[47]\right)$. The spectra also suggest that the surface composition was apparently Pd-rich by comparing the peak intensities with taking the sensitivity factors into consideration (the factor of $\mathrm{Pd} 3 d$ is $\sim 1.5$ times larger than Co $2 p[47])$. That is, Pd-skin was formed as often reported for Pt alloy catalysts of fuel cells $[48,49]$. The skin was probably formed by the dissolution of surface Co by air or Pd ions in the solution.

Figure 6 shows the electrochemical response of the PdCo film in an acid solution, compared with that of a pure $\mathrm{Pd}$ film. The cyclic voltammogram $(\mathrm{CV})$ of $\mathrm{PdCo}$ is similar
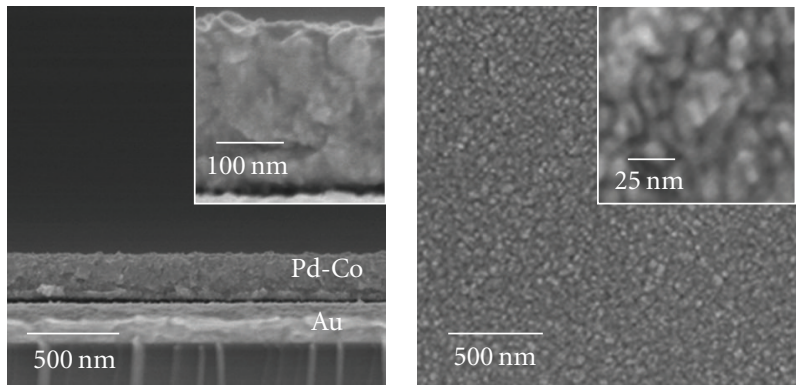

(a)
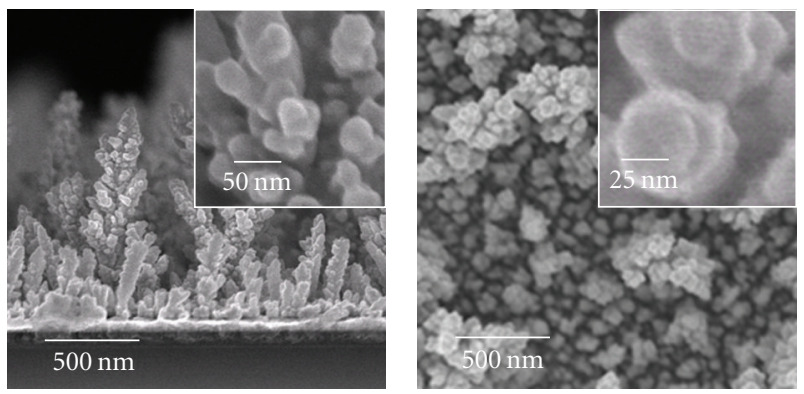

(b)
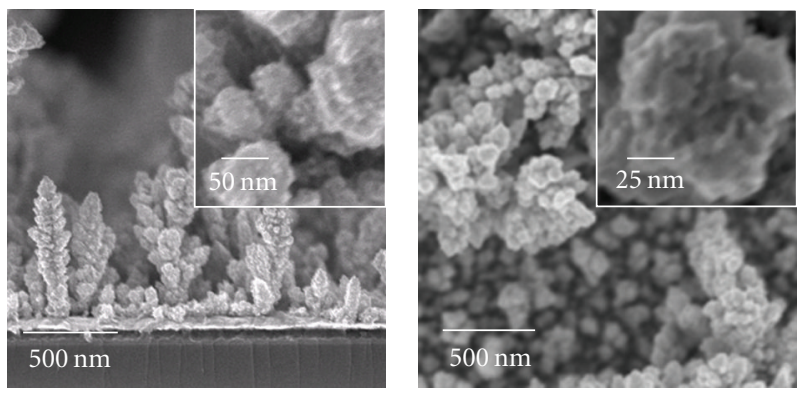

(c)

Figure 4: SEM images of PdCo alloys synthesized by electrodeposition: (a) at a low current density, (b) at a high current density, and (c) modification of the sample "b" by additional deposition. Left: cross-sectional view. Right: plan view. Reproduced with permission from [15]. Copyright 2007, The Electrochemical Society.

to that of $\mathrm{Pd}$, except for the sharp peaks obtained in the hydrogen region $(-0.2$ to $+0.1 \mathrm{~V})$. Since this $\mathrm{CV}$ trace of the PdCo film is similar to that of a nanostructured Pd (Pdblack), we assigned the peaks located in the hydrogen region in accordance with a report on nanostructured Pd [50]:

(i) Peak 1 (0.05 V): hydrogen adsorption/desorption for the surface Pd (strongly bound),

(ii) Peak $2(-0.05 \mathrm{~V})$ : hydrogen absorption/desorption for the subsurface $\operatorname{Pd}$ ( $\alpha$ and $\beta$ phases),

(iii) Peak $3(-0.2 \mathrm{~V})$ : hydrogen adsorption/desorption for the surface Pd or hydrogen evolution/oxidation reactions (less-strongly bound).

From this identification, it is found that the sharp peaks of PdCo (Peaks 1 and 3) strongly indicate the presence of Pdskin. Compared with pure Pd, the hydrogen absorption was found to be prevented by alloying with Co. 
TABLE 1: Oxygen reduction reaction characteristics of the PdCo catalysts evaluated in $0.5 \mathrm{M} \mathrm{H}_{2} \mathrm{SO}_{4}$ compared with those of Pt electrode and Pd electrode.

\begin{tabular}{|c|c|c|c|c|c|c|c|c|}
\hline & & $\begin{array}{r}\text { Elect } \\
\text { performance }\end{array}$ & $\begin{array}{l}\text { ode } \\
\mathrm{mA} \mathrm{cm}^{-2}\end{array}$ & Specific activit & $\mathrm{y}^{\mathrm{e}} / \mu \mathrm{Acm}^{-2}$ & & & \\
\hline & $\begin{array}{c}\text { Onset } \\
\text { potential }^{\text {a/V }}\end{array}$ & $\begin{array}{c}0.65 \mathrm{~V} \text { versus } \\
\mathrm{Ag} / \mathrm{AgCl}\end{array}$ & $\begin{array}{c}0.60 \mathrm{~V} \text { versus } \\
\mathrm{Ag} / \mathrm{AgCl}\end{array}$ & $\begin{array}{c}0.65 \mathrm{~V} \text { versus } \\
\mathrm{Ag} / \mathrm{AgCl}\end{array}$ & $\begin{array}{c}0.60 \mathrm{~V} \text { versus } \\
\mathrm{Ag} / \mathrm{AgCl}\end{array}$ & $\begin{array}{c}\text { Tafel slope/mV } \\
\text { decade }^{-1}\end{array}$ & $\begin{array}{l}\text { Roughness } \\
\text { factor/- }\end{array}$ & Ref. \\
\hline Pt electrode ${ }^{f}$ & 0.72 & $3.5 \times 10^{-2}$ & $1.1 \times 10^{-1}$ & 8.4 & $2.7 \times 10^{1}$ & $71^{\mathrm{c}}, 116^{\mathrm{d}}$ & 4.2 & {$[60]$} \\
\hline Pd thin film ${ }^{\mathrm{g}}$ & 0.58 & $1.0 \times 10^{-4 \mathrm{~h}}$ & $5.8 \times 10^{-4 \mathrm{~h}}$ & $3.4 \times 10^{-2 \mathrm{~h}}$ & $1.9 \times 10^{-1 \mathrm{~h}}$ & 67 & 3.1 & [11] \\
\hline PdCo thin film ${ }^{\mathrm{f}}$ & 0.66 & $2.4 \times 10^{-2}$ & $2.6 \times 10^{-1}$ & 1.5 & $1.6 \times 10^{1}$ & 44 & 16 & {$[60]$} \\
\hline PdCo dendrite ${ }^{g}$ & 0.68 & $5.7 \times 10^{-2}$ & $6.2 \times 10^{-1 \mathrm{~h}}$ & 4.4 & $4.7 \times 10^{1 \mathrm{~h}}$ & 48 & 13 & [15] \\
\hline Modified PdCo dendrite ${ }^{g}$ & 0.71 & $1.9 \times 10^{-1}$ & $1.6^{\mathrm{h}}$ & $1.1 \times 10^{1}$ & $9.2 \times 10^{1 \mathrm{~h}}$ & 55 & 17 & {$[15]$} \\
\hline Nanoporous PdCo thin film ${ }^{f}$ & 0.69 & $3.5 \times 10^{-1}$ & 2.5 & 8.6 & $6.2 \times 10^{1}$ & 43 & 41 & {$[60]$} \\
\hline Nanoporous PdCo dendrite ${ }^{g}$ & 0.72 & $3.9 \times 10^{-1 \mathrm{i}}$ & - & $1.3^{\mathrm{i}}$ & - & - & 290 & [29] \\
\hline
\end{tabular}

${ }^{\mathrm{a}}$ at the current density of $1 \mu \mathrm{A} \mathrm{cm}^{-2}$ (electrochemically active surface area). ${ }^{\mathrm{b}}$ based on the geometrical surface area. ${ }^{\mathrm{c}} 0.7-0.75 \mathrm{~V}$. ${ }^{\mathrm{d}} 0.55-0.65 \mathrm{~V}$. ${ }^{\mathrm{e}} \mathrm{based}$ on the electrochemically active surface area. ${ }^{\mathrm{f}}$ measured by hydrodynamic voltammetry at room temperature $\left(22^{\circ} \mathrm{C}\right) .{ }^{\mathrm{g}}$ measured by linear sweep voltammetry at $\left(30^{\circ} \mathrm{C}\right) .{ }^{\mathrm{h}}$ estimated by extrapolating the Tafel slope. ${ }^{\mathrm{i}}$ with a slight mass-transfer limitation.

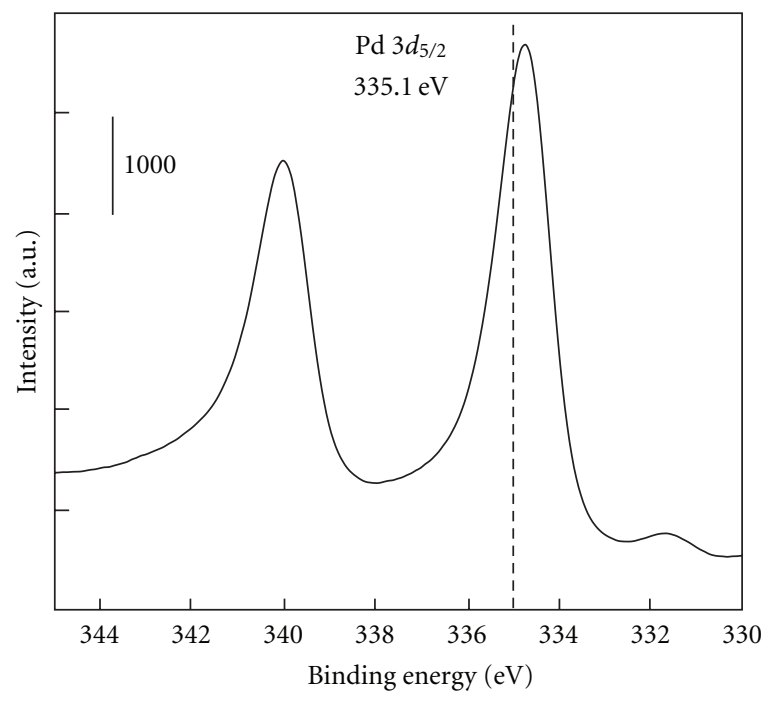

(a)

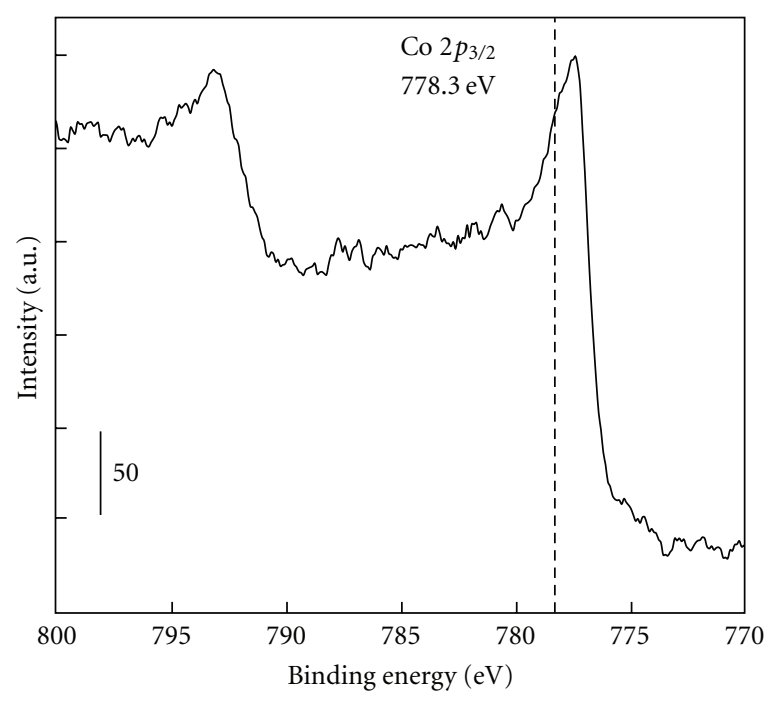

(b)

FIgure 5: Core-level XPS of PdCo thin film of Pd $3 d$ and Co $2 p$. The vertical dotted lines refer to Pd $3 d_{5 / 2}$ of pure Pd and Co $2 p_{3 / 2}$ of pure Co. The data of PdCo dendrites is consistent with this data. Reproduced with permission from [11]. Copyright 1986, Elsevier.

In the oxide region, the current densities from the PdCo are almost the same as that from the Pd, this meaning that the amount of sites binding with oxygen atoms is the same. However, the potential of oxide formation/deformation of the PdCo alloy was shifted to more negative potential, and this means that the Pd-skin is easily oxidized compared with pure Pd. This tendency was reported also by other groups [31]. Interestingly, this effect of the alloying on the oxide region is opposite to that of $\mathrm{Pt}$ alloys $[51,52]$ and to the prediction based on the shift of $d$-band center to a larger binding energy and the result of first-principle consideration $[31,53]$. Since the CV behavior in the potential region was dominated by adsorption of oxygenated species and desorption of sulfate anions, we speculate that the apparent negative shift of oxidation potential was probably due to the negative shift of sulfate desorption potential.

The current densities of the CVs were based on electrochemically active area $\left(A_{\mathrm{ec}}\right)$. Such area of Pt electrode has been calculated on the basis of hydrogen adsorption charge $[54,55]$, and that of Au electrode has been calculated on the basis of oxide reduction charge $[55,56]$; however, on Pd electrode, hydrogen absorption in hydrogen region and $\mathrm{Pd}$ dissolution in the oxide region make such charges unclear $[36,57]$. In view of this, we assumed that the double-layer capacitance $\left(C_{\mathrm{dl}}\right)$ per $A_{\mathrm{ec}}$ for Pd was the same as that for Pt. This assumption is acceptable, because the adsorbed-sulfate structure on a Pd electrode is similar to a Pt electrode. In detail, the adsorbed-sulfate structure was reported to be the 


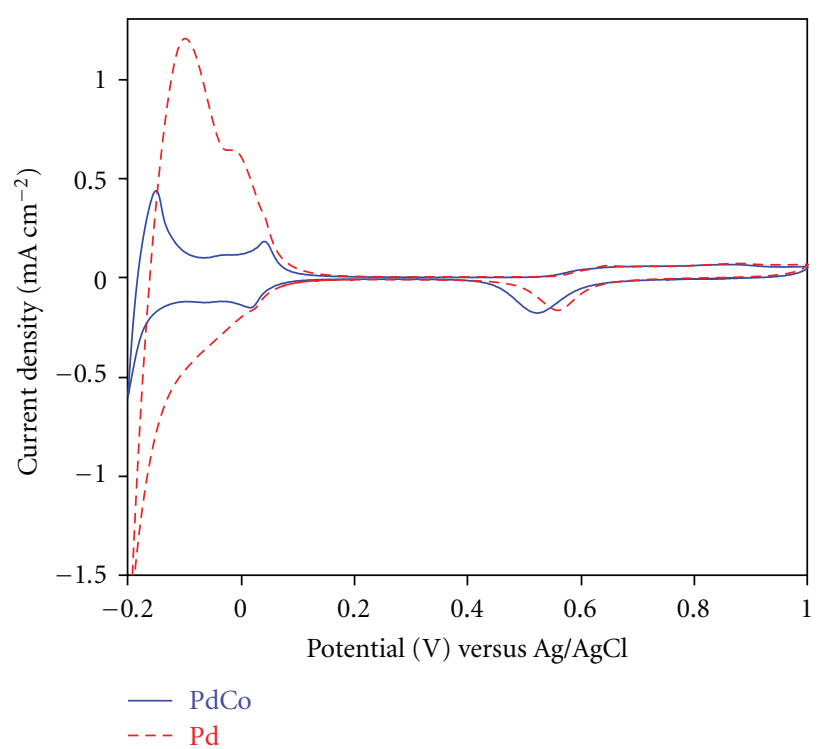

(a)

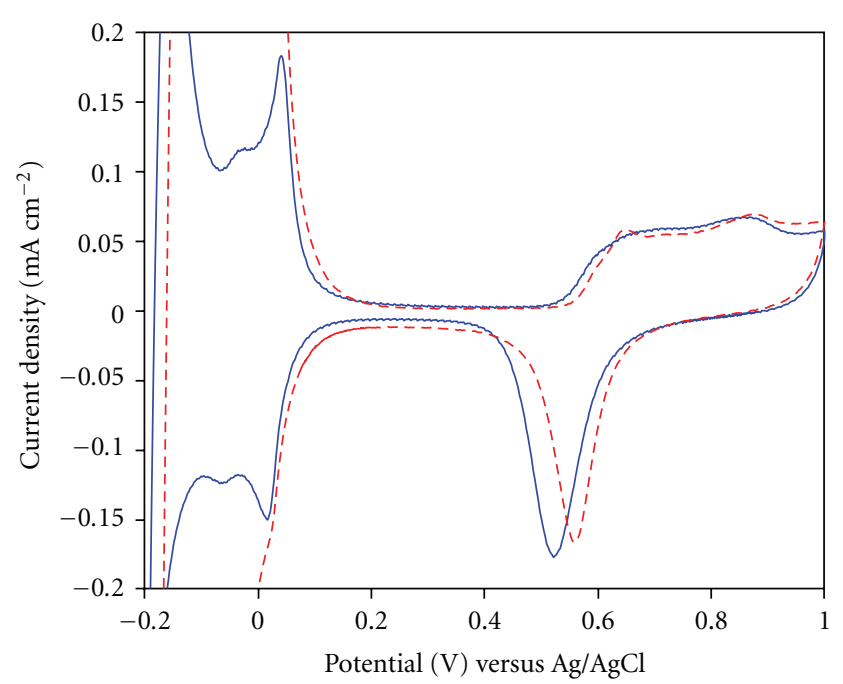

(b)

Figure 6: Cyclic voltammograms of the electrodeposited PdCo catalyst scanned at $50 \mathrm{mV} \mathrm{s}^{-1}$ in $0.5 \mathrm{M} \mathrm{H}_{2} \mathrm{SO}_{4}$ deaerated with $\mathrm{N}_{2}$ at lower (a) and at higher (b) expansion of current axis scale. The dotted line is a voltammogram of the electrodeposited Pd. The current density was normalized by electrochemical surface areas. Reproduced with permission from [11]. Copyright 1986, Elsevier.

same on (111) surface and slightly different on (100) surface $[58,59]$. We measured such capacitance for Pt by cyclic voltammetry, and a value of $86 \mu \mathrm{F} \mathrm{cm}^{-2}$ was obtained. Using this value, the electrochemically active surface areas of PdCo alloys were calculated.

For the successful improvement of microfuel cell performance, large surface area of catalyst is needed [5]. General direct methanol fuel cells require Pt loading of about $2.5 \mathrm{mg} \mathrm{cm}^{-2}$. This loading is translated into a roughness factor (a ratio of actual electrode surface area divided by geometrical one) of $2000\left(80 \mathrm{~m}^{2} \mathrm{~g}^{-1}\right)$ [39]. The value of the PdCo dendrite described above was 13.3. Even though longer deposition time was used, the value was limited to less than 100. This large gap is because the particles of the electrodeposited dendrites were more than ten times as big as the nanoparticles generally used for fuel cells. Thus, in order to increase the surface area of such electrodeposits, we have introduced nanopores into the electrodeposits by dealloying.

\section{Electrochemical Dealloying for Introducing Nanopores into Electrodeposits}

In order to increase the surface area of electrodeposited PdCo catalyst, we used dealloying technique as illustrated in Figure 1(a). First, a Co-rich PdCo alloy was electrodeposited, and then, the deposit was partially dealloyed by applying more positive potential in a sulfuric acid solution. A thin film of nanoporous PdCo catalyst was thus synthesized. Figure 7 shows that the dealloyed PdCo thin film was highly porous sponge-like film with $<50$-nm thick ligaments. The TEM images show crystalline ligaments whose lattice spacing was observed to be ca. $0.22 \mathrm{~nm}$, which is close to that of $\mathrm{Pd}(111)$ plane $(0.226 \mathrm{~nm})$. Interestingly, Figure $7(D)$ indicates that the ligament was formed by large crystal domains; namely, the ligaments were not composed of small particles, but of a long single crystal domain.

The as-deposited PdCo alloy of a nonporous fcc $\mathrm{Pd}_{30} \mathrm{Co}_{70}$ film became the sponge-like nanoporous $\mathrm{Pd}_{93} \mathrm{CO}_{7}$. In accordance with Vegard's law, since the peak angles of XRD pattern were shifted to higher angles [60], the crystal domains of the dealloyed PdCo alloy were found to be a substitutional solid solution of $\mathrm{Pd}_{92} \mathrm{Co}_{8}$. This degree of lattice contraction seems of great promise as ORR catalyst, because such a $8 \%$ lattice contraction was reported to endow Pd alloys with a high ORR activity [53].

The XPS results (Figure 8) show that the surface of this dealloyed thin film was Pd-rich, suggesting the formation of a Pd-skin layer as those of electrodeposited PdCo catalyst. The presence of Pd-skin was confirmed by CV measurement as shown in Figure 11. Compared with those of electrodeposited PdCo catalyst (Figure 5) and the as-deposited one (Figure 8), the dealloyed one had the $\mathrm{Pd} 3 d_{5 / 2}$ peak located at a slightly higher energy. Since the $\mathrm{Pd} 3 d_{5 / 2}$ peak energy located at $335.5 \mathrm{eV}$ is close to that of a metallic $\mathrm{Pd}(335.1 \mathrm{eV})$ rather than those of $\mathrm{Pd}$ oxides $\left(\mathrm{PdO}\right.$ at $336.3 \mathrm{eV}$ and $\mathrm{PdO}_{2}$ at $337.9 \mathrm{eV}$ ) [47], the Pd skin of the dealloyed one was still metallic. The slight shift toward higher energy probably suggested that the lattice of the Pd skin layer was contracted by the presence of subsurface PdCo alloy.

Since there was a concern about that, for use as an electrode for fuel cells, reactant transports seem hampered by their small and tortuous pores. On this point, we conceived that the macropores between dendrites formed by electrodeposition can compensate for the limitation. In 


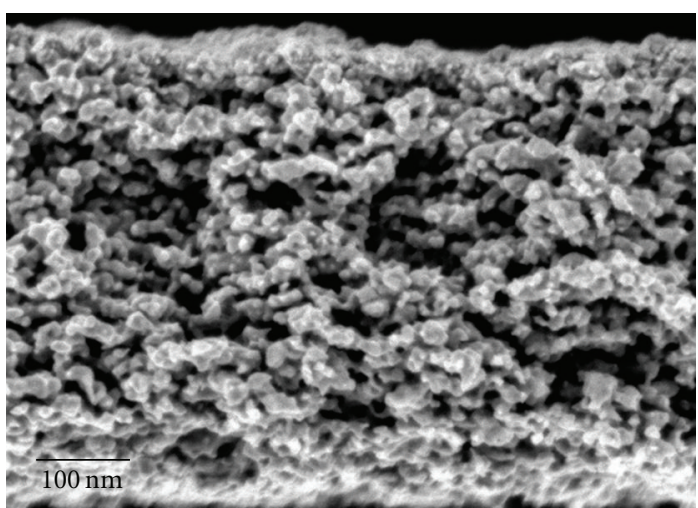

(A)

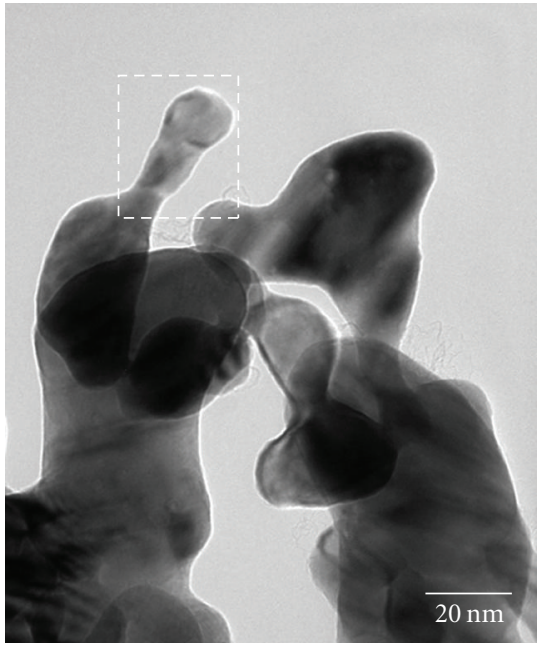

(C)

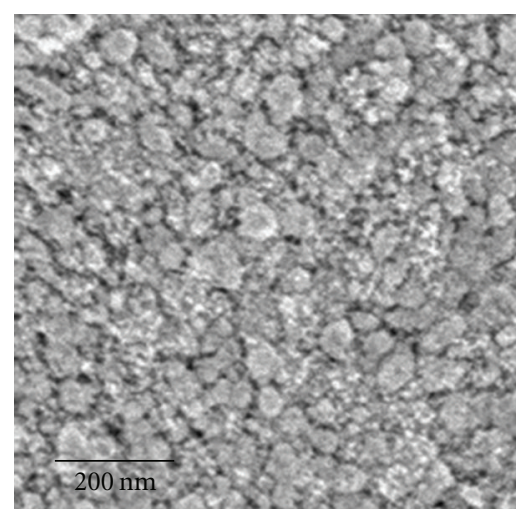

(B)

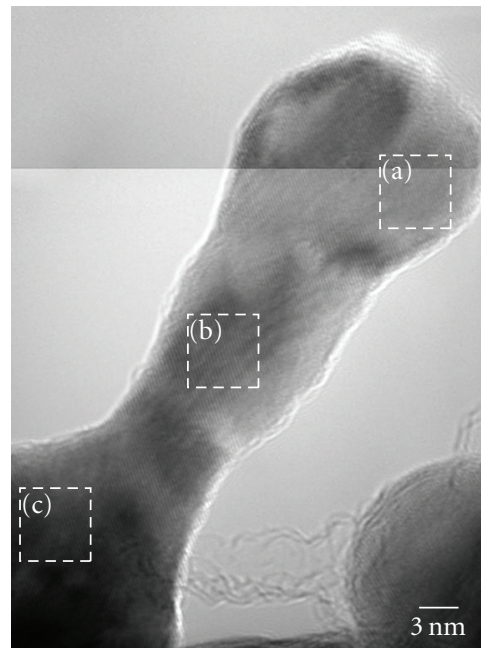

(D)

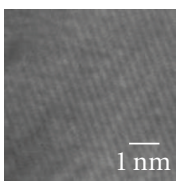

(a)

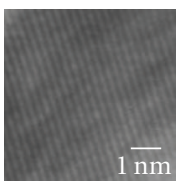

(b)

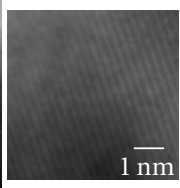

(c)

Figure 7: Electron micrographs of the dealloyed PdCo film. Cross-sectional (A) and (B) plan-view SEM images. (C, D) TEM images. (a-c) High-resolution images of lattice fringes with a lattice distance of $2.2 \AA$. Reproduced with permission from [27]. Copyright 2010, RSC.

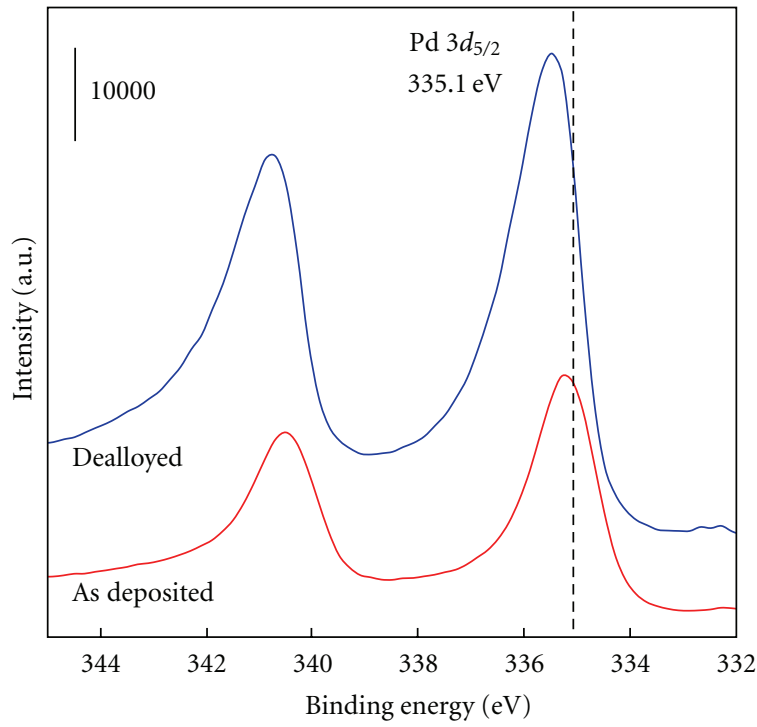

(a)

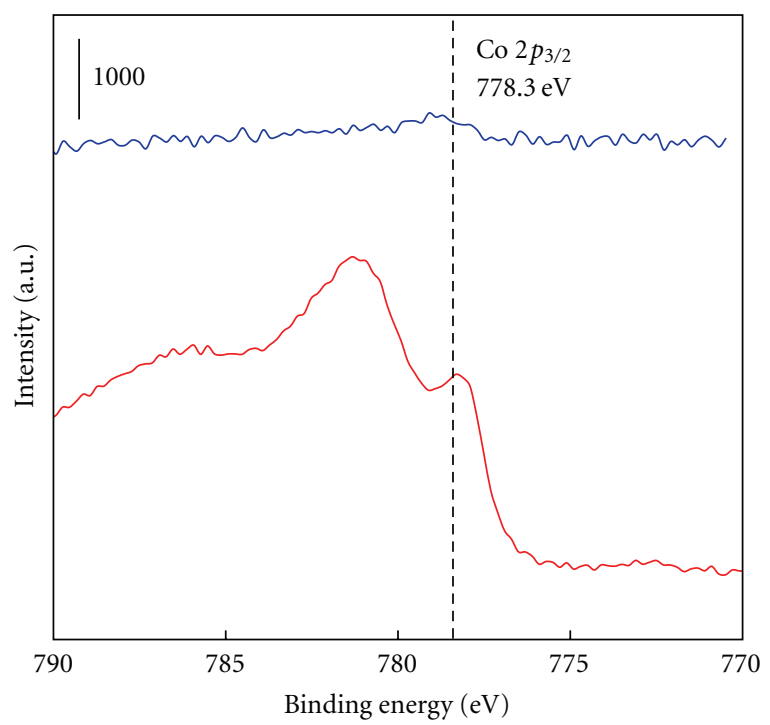

(b)

FIgure 8: Core-level XPS of the nanoporous PdCo thin film of Pd $3 d$ and Co $2 p$. The vertical dotted lines refer to Pd $3 d_{5 / 2}$ of pure Pd and Co $2 p_{3 / 2}$ of pure Co. Reproduced with permission from [27]. Copyright 2010, RSC. 


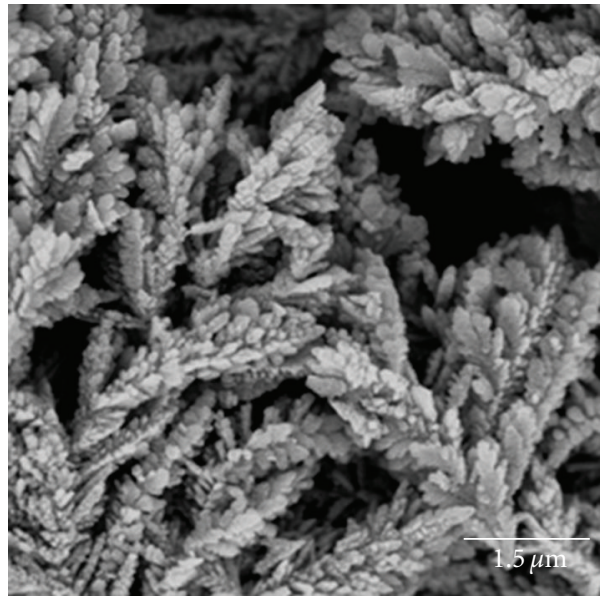

(a)

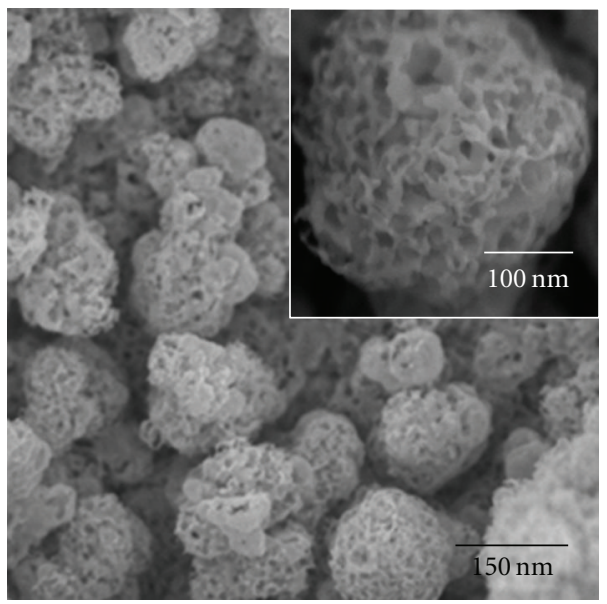

(c)

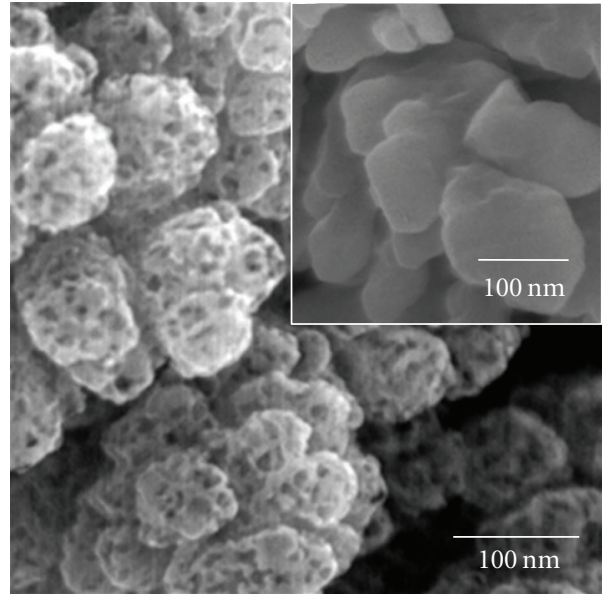

(b)

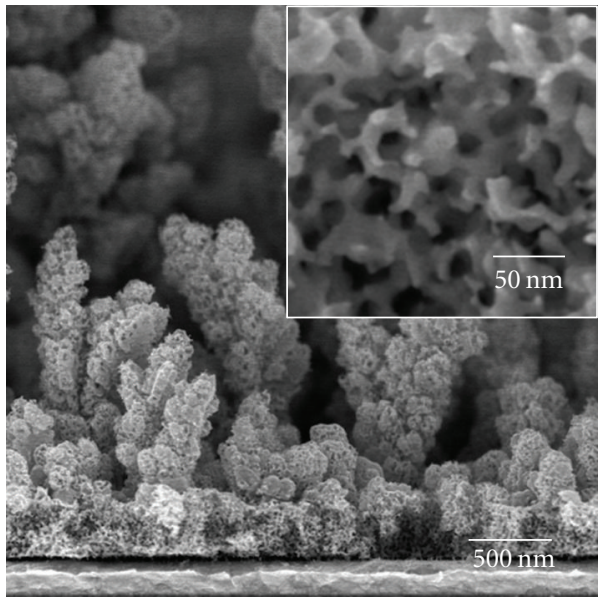

(d)

FIGURE 9: SEM images of nanoporous PdCo dendrites: (a-c) plan view, and (d) cross-sectional. The sample shown in "a" and "b" was electrodeposited at a constant current of $-50 \mathrm{~mA} \mathrm{~cm}^{-2}$ for $600 \mathrm{~s}$ followed by the immersion in an air-saturated $0.5 \mathrm{M}$ sulfuric acid solution for $\sim 15 \mathrm{~h}$ at $60^{\circ} \mathrm{C}$. The sample shown in " $\mathrm{c}$ " and " $\mathrm{d}$ " was prepared by galvanic pulse deposition and dealloying. Reproduced with permission from [29]. Copyright 2010, Elsevier.

this view, we proposed a simple method to synthesize a unique nanostructure with both a hierarchical porosity and a large surface area, that is nanoporous dendrites, which have macropores between dendrites formed by electrodeposition and nanopores formed by dealloying (Figure 1(b)).

Likewise, the dealloying of dendritic structures resulted in the nanoporous dendrites as shown in Figures 9 and 10. Compared with as-deposited ones, the nanopores were found to be formed without changing the macroscopic morphology of dendrites (Figure 9(b)). The dendrites consisted of $100-300 \mathrm{~nm}$ nanoparticles having $\sim 10 \mathrm{~nm}$ nanopores. The sponge-like porous structure is typical for the metal architecture prepared by dealloying. Since the lattice fringes were observed to be aligned over nanopores (Figure 10(c)), the crystallites were found to be larger than the ligaments. The whole deposited layer was thin enough $(4-5 \mu \mathrm{m})$ for use as a catalyst for on-chip fuel cells [1]. The macropores between the deposits are expected to make the entire surface of the dendrites readily accessible by oxygen.
The bulk composition and crystal structure were changed from amorphous $\mathrm{Pd}_{24} \mathrm{Co}_{76}$ (as-deposited one) to a polycrystalline fcc crystals of $\mathrm{Pd}_{79} \mathrm{Co}_{21}$, whose XRD pattern was well consistent with that of a pure fcc Pd. The surface composition was determined to be nearly pure metallic Pd by XPS, which corresponds to the results shown in Figure 5. This layer probably protected the residual Co atoms in the subsurface alloy phases from leaching out. As we described above, Pd atoms in some easily dissolvable phases, for example, solid solutions and intermetallic compounds of $\mathrm{PdCo}_{3}$ ( $\mathrm{L}_{2}$ phase) [42], probably resulted in thick Pd skin layers that incorporated some relatively stable phases, for example, fcc $\mathrm{Pd}_{3} \mathrm{Co}\left(\mathrm{L}_{2}\right.$ phase) and fct $\mathrm{Pd}_{1} \mathrm{Co}_{1}$ ( $\mathrm{L}_{0}$ phase).

Electron diffraction (Figure $10(\mathrm{~d})$ ) reveals such presence of alloy domains. The diffraction pattern is assignable to a face-centered tetragonal structure with lattice parameters of $a=4.9 \AA$ and $c=2.5 \AA$, or a hexagonal close packing (hcp) structure with lattice parameters of $a=2.8 \AA$ and $c=$ 4.1 $\AA$, observed at [111] direction (for determining details, 


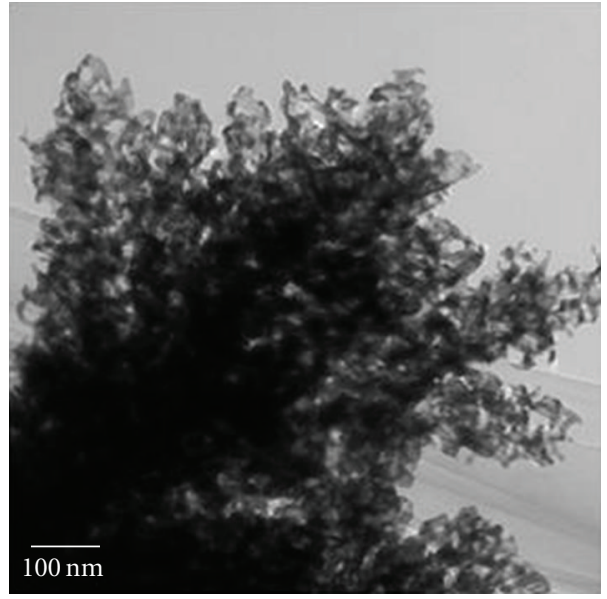

(a)

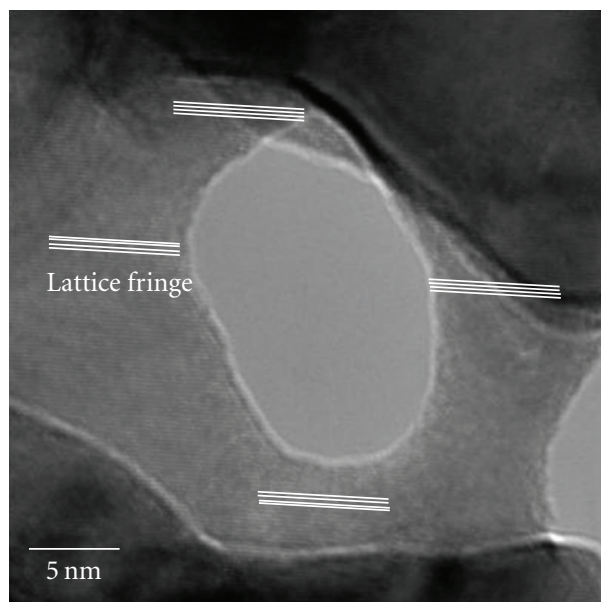

(c)

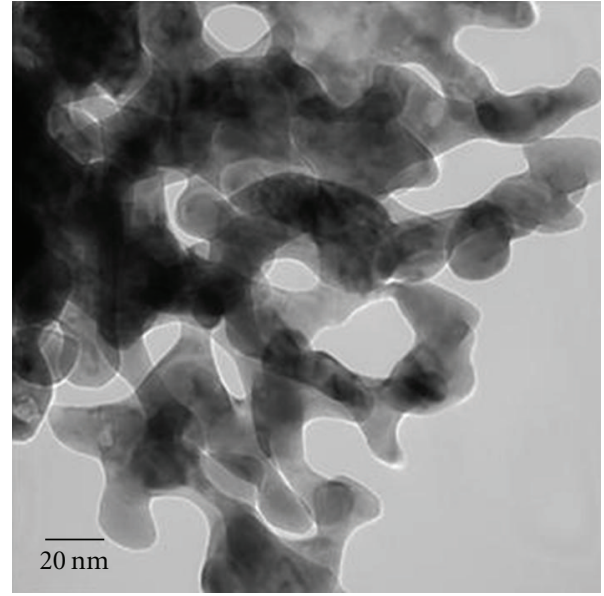

(b)

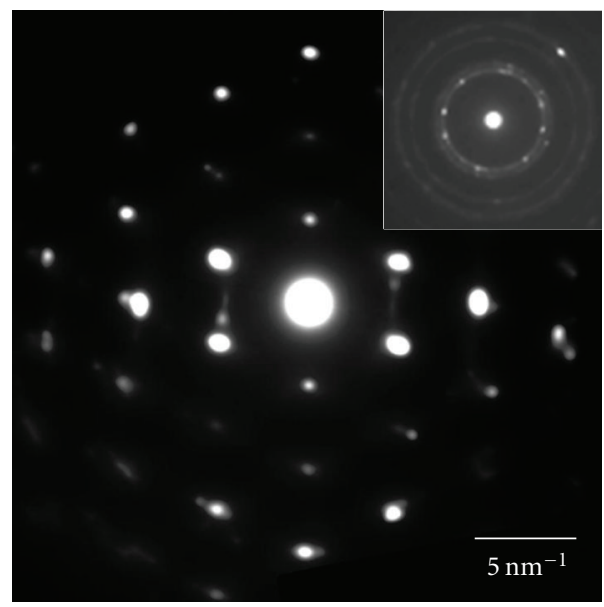

(d)

Figure 10: TEM images $(\mathrm{a}-\mathrm{c})$ and selected-area electron diffraction pattern (d) of nanoporous PdCo dendrites synthesized by the combination of electrodeposition and dealloying. The parallel lines in "c" show the direction of lattice fringes. The diffraction pattern was collected at $200 \mathrm{kV}$ with a camera length of $1.0 \mathrm{~m}$. The inset in "d" is another diffraction pattern. Reproduced with permission from [29]. Copyright 2010, RSC.

further investigation is needed). Compared with fcc Pd ( $a=$ $3.90 \AA)$, fcc Co $(a=3.54 \AA)$ and hcp Co $(a=2.51 \AA$ and $c=$ $4.09 \AA$ ), whichever, this pattern can be assignable to an alloy phase. In addition, we could obtain weak polycrystalline fcc ED pattern as shown in the inset, this might be assignable to the surface Pd skin layer, considering the fact that a fcc pattern was obtained by XRD. Thus, we can conclude that the nanoporous dendrites contained both crystalline pure Pd skin layer and fct or hcp PdCo alloy phase.

\section{Comparison as Catalyst Layers for Microfuel Cells}

Figure 11 compares CVs of the PdCo catalysts synthesized. Electrochemical response of the nanoporous dendrite was apparently larger than nanoporous thin film and nonporous dendrite. The roughness factor of the nanoporous dendrite was determined to be ca. 290. This value is more than twentyfold of the value of the PdCo dendrite without nanopores (ca. 13), indicating a positive effect of the formation of nanopores even though the nanoporous one is a few times thicker than the nonporous one (ca. $1.5 \mu \mathrm{m})$. This quite large surface area is expected to improve the electrode performance. The roughness factors were compared also in Table 1.

ORR activities of the PdCo catalysts synthesized are compared in Table 1. Apparently, the electrode performances of the nanoporous catalysts are higher than those of nonporous ones, and the nanoporous dendrite exhibited the best performance. This is simply because of its large surface area. The onset potentials were $\sim 0.7 \mathrm{~V}$ versus $\mathrm{Ag} / \mathrm{AgCl}$, which is by $0.1 \mathrm{~V}$ more positive than pure Pd catalyst and comparable to pure Pt catalyst. In terms of specific activity, most of PdCo alloys were comparable to Pt catalyst at $0.65 \mathrm{~V}$ and became better at $0.60 \mathrm{~V}$. Thus, we confirmed positive effect of alloying.

The activity of nanoporous PdCo thin film was $\sim 200$ times higher than that of pure Pd catalyst and still a few times 


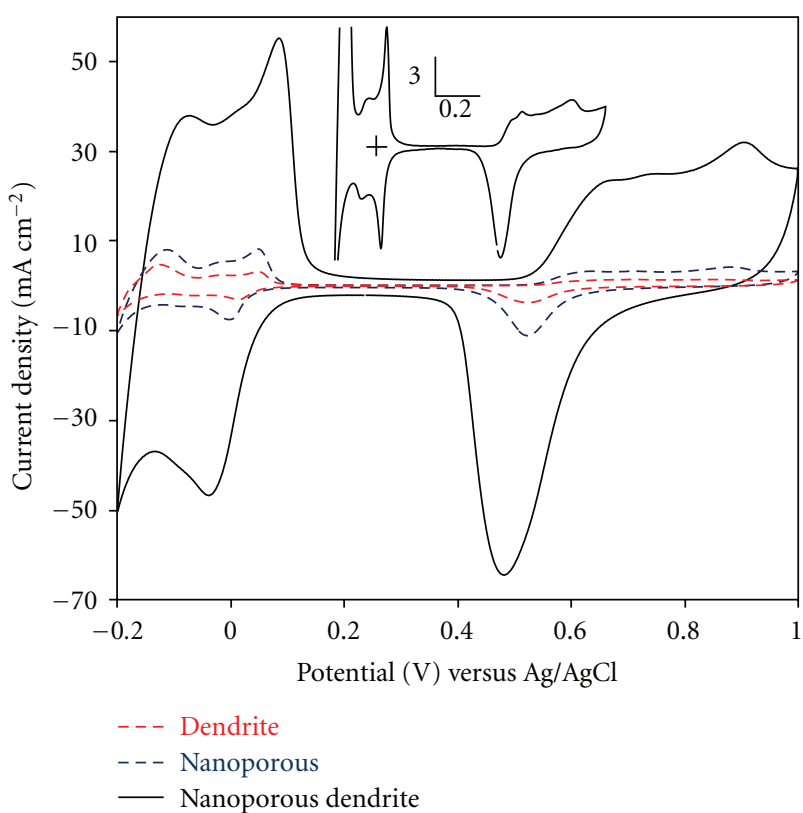

Figure 11: Comparison of cyclic voltammograms of the PdCo dendrite (dashed red line), nanoporous PdCo thin film (dotted blue line), and nanoporous PdCo dendrite (black solid line) scanned in $0.5 \mathrm{M} \mathrm{H}_{2} \mathrm{SO}_{4}$ deaerated with $\mathrm{N}_{2}$ at $50 \mathrm{mV} \mathrm{s}^{-1}$. The inset shows voltammogram of the nanoporous dendrite scanned at $5 \mathrm{mV} \mathrm{s}^{-1}$.

higher than the PdCo alloys which did not exhibit the apparent peak shift of Pd $3 d$ XPS (i.e., PdCo dendrite, PdCo thin film and nanoporous PdCo dendrite). Therefore, we conclude that the lattice contraction of the surface Pd-skin is the most important, and the nanoporous PdCo thus obtained had an active surface as well as the large surface area.

The higher activity than Pt catalyst is because of the preferably small Tafel slope, which indicates that the ratedetermining step of ORR on the nanoporous PdCo thin film was different from Pt catalyst. As discussed previously [60], all of the PdCo catalysts synthesized by electrochemical methods had small Tafel slopes as shown in Table 1. Those values are apparently smaller than those of PdCo catalysts synthesized by other techniques $\left(60-70 \mathrm{mV}\right.$ decade $\left.^{-1}\right)$. This unique property of such PdCo catalysts synthesized by electrochemical techniques is of significant importance for developing effective catalysts.

\section{Conclusions}

We have synthesized PdCo catalysts for microfuel cells by electrodeposition and electrochemical dealloying. The former technique successfully synthesized PdCo alloys selectively onto conductive Au substrates, and by changing the potential applied, morphologies of the deposits were tuned into thin films or dendrites. The latter technique successfully increased the electrochemically active surface area by roughly ten times. Thus, such combination of electrodeposition and dealloying was proved effective for synthesizing highperformance electrodes for microsystems.

In terms of fuel cell catalyst, the PdCo nanostructures exhibited better activity for oxygen reduction reaction than
Pt catalyst, especially in the potential range of interest for actual fuel cell operation ( $0.8 \mathrm{~V}$ versus NHE). This is because of the smaller Tafel slope value of our PdCo catalysts. We believe that detailed analyses on such unique Tafel slope values, which have been obtained only for such PdCo catalysts synthesized by electrochemical methods, are needed and of quite importance for developing effective fuel cell catalysts.

\section{Experimental}

6.1. Synthesis. PdCo thin film was electrodeposited at $-10 \mathrm{~mA} \mathrm{~cm}^{-2}$ for $60 \mathrm{~s}$, and PdCo dendrite was deposited at $-200 \mathrm{~mA} \mathrm{~cm}^{-2}$ for $5 \mathrm{~s}$. The dendrite was modified by further deposition at $-0.75 \mathrm{~V}$ versus $\mathrm{Ag} / \mathrm{AgCl}$ for $10 \mathrm{~s}$. This potential was consistent with the deposition potential of the PdCo thin film at $-10 \mathrm{~mA} \mathrm{~cm}^{-2}$. The deposition bath contained $76 \mathrm{mM}$ $\left[\mathrm{Pd}\left(\mathrm{NH}_{3}\right)_{4}\right] \mathrm{Cl}_{2}, 34 \mathrm{mM} \mathrm{CoCl}_{2}, 78 \mathrm{mM} \mathrm{NH}_{4} \mathrm{Cl}$ and $120 \mathrm{mM}$ malonic acid ( $\mathrm{pH}=9.1$, adjusted by $\left.\mathrm{NH}_{4} \mathrm{OH}\right)$.

Nanoporous PdCo flat film was synthesized as follows. First, Co-rich PdCo thin film was electrodeposited at $-0.9 \mathrm{~V}$ versus $\mathrm{Ag} / \mathrm{AgCl}$ for $10 \mathrm{~min}$ in a solution containing $34 \mathrm{mM}$ $\left[\mathrm{Pd}\left(\mathrm{NH}_{3}\right)_{4}\right] \mathrm{Cl}_{2}, 76 \mathrm{mM} \mathrm{CoCl}_{2}, 76 \mathrm{mM} \mathrm{NH}_{4} \mathrm{Cl}$ and $268 \mathrm{mM}$ malonic acid at $14 \pm 2{ }^{\circ} \mathrm{C}$. This solution was prepared by mixing (i) a Pd solution containing $68 \mathrm{mM}\left[\mathrm{Pd}\left(\mathrm{NH}_{3}\right)_{4}\right] \mathrm{Cl}_{2}$ and $152 \mathrm{mM} \mathrm{NH}_{4} \mathrm{Cl}\left(\mathrm{pH}=10\right.$ adjusted by $\left.\mathrm{NH}_{4} \mathrm{OH}\right)$ and (ii) a Co solution containing $152 \mathrm{mM} \mathrm{CoCl}_{2}$ and $536 \mathrm{mM}$ malonic acid ( $\mathrm{pH}=10$ adjusted by $\mathrm{NH}_{4} \mathrm{OH}$ ), in a volume ratio of $1: 1$. Then, the solution was aged for 3 days at $14^{\circ} \mathrm{C}$. The PdCo film thus obtained was electrochemically dealloyed for $6 \mathrm{~h}$ at $0.6 \mathrm{~V}$ in $0.5 \mathrm{M} \mathrm{H}_{2} \mathrm{SO}_{4}$ deaerated with $\mathrm{N}_{2}\left(\sim 22^{\circ} \mathrm{C}\right)$.

Nanoporous PdCo dendrites with hierarchical porosity were synthesized as follows. First, Co-rich PdCo dendrites were electrodeposited by applying a galvanic pulse (on: $-40 \mathrm{~mA} \mathrm{~cm}^{-2}$ for $1 \mathrm{~s}$; off: $2 \mathrm{~s} ; 500$ cycles) in a bath of the same composition for synthesizing nanoporous thin film but without the aging treatment. Then, the electrodeposits were dealloyed by immersing in an air-saturated $0.5 \mathrm{M} \mathrm{H}_{2} \mathrm{SO}_{4}$ at $60^{\circ} \mathrm{C}$ overnight $(\sim 15 \mathrm{~h})$.

For these deposition experiments, a conventional threeelectrode cell was used. The reference and the counter electrodes were a $\mathrm{Ag} / \mathrm{AgCl}$ ( $\mathrm{KCl}$-saturated) electrode and a Pt coil, respectively. The working electrode was a flat $\mathrm{Au}$ thin film (200 nm thick), which was deposited on silicon substrate with $20-\mathrm{nm} \mathrm{Ti}$ adhesion layer by electron-beam evaporation [11].

6.2. Characterization. The morphology was observed using a high-resolution scanning electron microscope (HR-SEM) (S5500, Hitachi). The composition was determined by energy dispersive X-ray fluorescence spectroscopy or by inductively coupled plasma atomic emission spectroscopy. The surface composition and the surface elemental state were evaluated by X-ray photoelectron spectroscopy (XPS) using an $\mathrm{Mg}$ target. The crystal structure was examined by means of X-ray diffractometry (XRD) using a $\mathrm{Cu} \mathrm{K} \alpha$ radiation.

The surfaces of the synthesized catalysts were electrochemically cleaned by scanning in a $0.5 \mathrm{M} \mathrm{H}_{2} \mathrm{SO}_{4}$ solution deaerated with $\mathrm{N}_{2}$ in the potential range of +0.2 to $1.0 \mathrm{~V}$ versus $\mathrm{Ag} / \mathrm{AgCl}$ at $50 \mathrm{mV} \mathrm{s}^{-1}$. The electrochemical response 
was evaluated by cyclic voltammetry (CV) in a $0.5 \mathrm{M} \mathrm{H}_{2} \mathrm{SO}_{4}$ deaerated with $\mathrm{N}_{2}$ in the potential range of -0.2 to $+1.0 \mathrm{~V}$ versus $\mathrm{Ag} / \mathrm{AgCl}$ at $50 \mathrm{mV} \mathrm{s}^{-1}$. The roughness factor was calculated based on the double-layer capacitance in the CVs $\left(8.6 \mathrm{mF} \mathrm{cm}^{-2}\right)$ [11]. The activity for the oxygen reduction reaction was evaluated by linear sweep voltammetry (LSV) in an oxygen-saturated $0.5 \mathrm{M} \mathrm{H}_{2} \mathrm{SO}_{4}$ solution from the open circuit potential.

\section{Acknowledgments}

This work was partly supported by Grant-in-Aid for Specially Promoted Research "Establishment of Electrochemical Device Engineering" and by the Global COE program "Practical Chemical Wisdom" from the Ministry of Education, Culture, Sports, Science, and Technology (MEXT), Japan. S. Tominaka acknowledges Grant-in-Aid for Young Scientists B (22750174) and World Premier International Research Center Initiative (WPI Initiative) on "Materials Nanoarchitronics", MEXT, Japan.

\section{References}

[1] S. Tominaka, S. Ohta, H. Obata, T. Momma, and T. Osaka, "On-chip fuel cell: micro direct methanol fuel cell of an airbreathing, membraneless, and monolithic design," Journal of the American Chemical Society, vol. 130, no. 32, pp. 1045610457, 2008.

[2] S. Motokawa, M. Mohamedi, T. Momma, S. Shoji, and T. Osaka, "MEMS-based design and fabrication of a new concept micro direct methanol fuel cell ( $\mu$-DMFC)," Electrochemistry Communications, vol. 6, no. 6, pp. 562-565, 2004.

[3] S. Tominaka, H. Nishizeko, S. Ohta, and T. Osaka, "On-chip fuel cells for safe and high-power operation: investigation of alcohol fuel solutions," Energy and Environmental Science, vol. 2, no. 8, pp. 849-852, 2009.

[4] S. Tominaka, H. Obata, and T. Osaka, "On-chip direct methanol fuel cells of a monolithic design: consideration on validity of active-type system," Energy and Environmental Science, vol. 2, no. 8, pp. 845-848, 2009.

[5] S. Tominaka, S. Ohta, T. Osaka, and R. Alkire, "Prospects of on-chip fuel cell performance: improvement based on numerical simulation," Energy and Environmental Science, vol. 4, no. 1, pp. 162-171, 2011.

[6] S. Tominaka, H. Nishizeko, J. Mizuno, and T. Osaka, "Bendable fuel cells: on-chip fuel cell on a flexible polymer substrate," Energy and Environmental Science, vol. 2, no. 10, pp. 1074-1077, 2009.

[7] H. Nakano, K. Dokko, J. I. Sugaya, T. Yasukawa, T. Matsue, and K. Kanamura, "All-solid-state micro lithium-ion batteries fabricated by using dry polymer electrolyte with micro-phase separation structure," Electrochemistry Communications, vol. 9, no. 8, pp. 2013-2017, 2007.

[8] D. Golodnitsky, V. Yufit, M. Nathan et al., "Advanced materials for the 3D microbattery," Journal of Power Sources, vol. 153, no. 2, pp. 281-287, 2006.

[9] D. Niwa, K. Omichi, N. Motohashi, T. Homma, and T. Osaka, "Organosilane self-assembled monolayer-modified field effect transistors for on-chip ion and biomolecule sensing," Sensors and Actuators, vol. 108, no. 1-2, pp. 721-726, 2005.

[10] R. Popovtzer, T. Neufeld, D. Biran, E. Z. Ron, J. Rishpon, and Y. Shacham-Diamand, "Novel integrated electrochemical nanobiochip for toxicity detection in water," Nano Letters, vol. 5, no. 6, pp. 1023-1027, 2005.
[11] S. Tominaka, T. Momma, and T. Osaka, "Electrodeposited PdCo catalyst for direct methanol fuel cell electrodes: preparation and characterization," Electrochimica Acta, vol. 53, no. 14, pp. 4679-4686, 2008.

[12] T. Osaka, H. Ilda, S. Tominaka, and T. Hachisu, "New trends in nanoparticles: syntheses and their applications to fuel cells, health care, and magnetic storage," Israel Journal of Chemistry, vol. 48, no. 3-4, pp. 333-347, 2008.

[13] M. Paunovic and M. Schlesinger, Fundamentals of Electrochemical Deposition, John Wiley \& Sons, Hoboken, NJ, USA, 2006.

[14] R. M. Penner, "Hybrid electrochemical/chemical synthesis of quantum dots," Accounts of Chemical Research, vol. 33, no. 2, pp. 78-86, 2000.

[15] S. Tominaka, S. Ohta, T. Momma, and T. Osaka, "An electrodeposited Pd-Co cathode catalyst for a microfabricated direct methanol fuel cell," in Proceedings of the 212th ECS Meeting, vol. 11, pp. 1369-1377, Washington, DC, USA, October 2007.

[16] Y. Yamauchi, H. Kitoh, T. Momma, T. Osaka, and K. Kuroda, "Development of microfabrication process of mesoporous $\mathrm{Pt}$ via "Solvent-Evaporation-Mediated Direct Physical Casting": selective deposition into sloped microchannels," Science and Technology of Advanced Materials, vol. 7, no. 5, pp. 438-445, 2006.

[17] G. S. Attard, P. N. Bartlett, N. R. B. Coleman, J. M. Elliott, J. R. Owen, and J. H. Wang, "Mesoporous platinum films from lyotropic liquid crystalline phases," Science, vol. 278, no. 5339, pp. 838-840, 1997.

[18] S. Tominaka, C. W. Wu, T. Momma, K. Kuroda, and T. Osaka, "Perpendicular mesoporous Pt thin films: electrodeposition from titania nanopillars and their electrochemical properties," Chemical Communications, no. 25, pp. 2888-2890, 2008.

[19] Y. Yamauchi and K. Kuroda, "Rational design of mesoporous metals and related nanomaterials by a soft-template approach," Chemistry, vol. 3, no. 4, pp. 664-676, 2008.

[20] J. Erlebacher, M. J. Aziz, A. Karma, N. Dimitrov, and K. Sieradzki, "Evolution of nanoporosity in dealloying," Nature, vol. 410, no. 6827, pp. 450-453, 2001.

[21] J. Rugolo, J. Erlebacher, and K. Sieradzki, "Length scales in alloy dissolution and measurement of absolute interfacial free energy," Nature Materials, vol. 5, no. 12, pp. 946-949, 2006.

[22] K. Wagner, S. R. Brankovic, N. Dimitrov, and K. Sieradzki, "Dealloying below the critical potential," Journal of the Electrochemical Society, vol. 144, no. 10, pp. 3545-3555, 1997.

[23] K. Sieradzki, N. Dimitrov, D. Movrin, C. McCall, N. Vasiljevic, and J. Erlebacher, "The dealloying critical potential," Journal of the Electrochemical Society, vol. 149, no. 8, pp. B370-B377, 2002.

[24] J. Erlebacher, "An atomistic description of dealloying porosity evolution, the critical potential, and rate-limiting behavior," Journal of the Electrochemical Society, vol. 151, no. 10, pp. C614-C626, 2004.

[25] Y. Ding, M. Chen, and J. Erlebacher, "Metallic mesoporous nanocomposites for electrocatalysis," Journal of the American Chemical Society, vol. 126, no. 22, pp. 6876-6877, 2004.

[26] S. Tominaka, T. Hayashi, Y. Nakamura, and T. Osaka, "Mesoporous PdCo sponge-like nanostructure synthesized by electrodeposition and dealloying for oxygen reduction reaction," Journal of Materials Chemistry, vol. 20, no. 34, pp. 7175-7182, 2010.

[27] S. Tominaka, "Facile synthesis of nanostructured gold for microsystems by the combination of electrodeposition and dealloying," Journal of Materials Chemistry, vol. 21, pp. 97259730, 2011. 
[28] S. Tominaka, M. Shigeto, H. Nishizeko, and T. Osaka, "Synthesis of mesoporous $\mathrm{PtCu}$ film modified with $\mathrm{Ru}$ submonolayer as catalyst for methanol electrooxidation," Chemical Communications, vol. 46, no. 47, pp. 8989-8991, 2010.

[29] S. Tominaka, Y. Nakamura, and T. Osaka, "Nanostructured catalyst with hierarchical porosity and large surface area for on-chip fuel cells," Journal of Power Sources, vol. 195, no. 4, pp. 1054-1058, 2010.

[30] J. L. Fernández, V. Raghuveer, A. Manthiram, and A. J. Bard, "Pd-Ti and Pd-Co-Au electrocatalysts as a replacement for platinum for oxygen reduction in proton exchange membrane fuel cells," Journal of the American Chemical Society, vol. 127, no. 38, pp. 13100-13101, 2005.

[31] K. Lee, O. Savadogo, A. Ishihara, S. Mitsushima, N. Kamiya, and K. I. Ota, "Methanol-tolerant oxygen reduction electrocatalysts based on Pd-3D transition metal alloys for direct methanol fuel cells," Journal of the Electrochemical Society, vol. 153, no. 1, pp. A20-A24, 2006.

[32] W. E. Mustain, K. Kepler, and J. Prakash, "Investigations of carbon-supported CoPd3 catalysts as oxygen cathodes in PEM fuel cells," Electrochemistry Communications, vol. 8, no. 3, pp. 406-410, 2006.

[33] W. E. Mustain, K. Kepler, and J. Prakash, "CoPdx oxygen reduction electrocatalysts for polymer electrolyte membrane and direct methanol fuel cells," Electrochimica Acta, vol. 52, no. 5, pp. 2102-2108, 2007.

[34] V. Raghuveer, A. Manthiram, and A. J. Bard, "Pd-Co-Mo electrocatalyst for the oxygen reduction reaction in proton exchange membrane fuel cells," Journal of Physical Chemistry B, vol. 109, no. 48, pp. 22909-22912, 2005.

[35] O. Savadogo, K. Lee, K. Oishi, S. Mitsushima, N. Kamiya, and K. -I. Ota, "New palladium alloys catalyst for the oxygen reduction reaction in an acid medium," Electrochemistry Communications, vol. 6, no. 2, pp. 105-109, 2004.

[36] M. Grden, M. Lukaszewski, G. Jerkiewicz, and A. Czerwinski, "Electrochemical behaviour of palladium electrode: oxidation, electrodissolution and ionic absorption," Electrochimica Acta, vol. 53, pp. 7583-7598, 2008.

[37] J. L. Fernández, D. A. Walsh, and A. J. Bard, “Thermodynamic guidelines for the design of bimetallic catalysts for oxygen electroreduction and rapid screening by scanning electrochemical microscopy. M-Co (M: Pd, Ag, Au)," Journal of the American Chemical Society, vol. 127, no. 1, pp. 357-365, 2005.

[38] V. Raghuveer, P. J. Ferreira, and A. Manthiram, "Comparison of Pd-Co-Au electrocatalysts prepared by conventional borohydride and microemulsion methods for oxygen reduction in fuel cells," Electrochemistry Communications, vol. 8, no. 5, pp. 807-814, 2006.

[39] M. H. Shao, T. Huang, P. Liu et al., "Palladium monolayer and palladium alloy electrocatalysts for oxygen reduction," Langmuir, vol. 22, no. 25, pp. 10409-10415, 2006.

[40] Y. Wang and P. B. Balbuena, "Design of oxygen reduction bimetallic catalysts: ab-initio-derived thermodynamic guidelines," Journal of Physical Chemistry B, vol. 109, no. 40, pp. 18902-18906, 2005.

[41] L. Zhang, K. Lee, and J. Zhang, "The effect of heat treatment on nanoparticle size and ORR activity for carbon-supported Pd-Co alloy electrocatalysts," Electrochimica Acta, vol. 52, no. 9, pp. 3088-3094, 2007.

[42] T. Mallát, J. Petró, S. Szabó, and L. Marczis, "Investigation of Pd + Co alloys by the linear potential sweep method," Journal of Electroanalytical Chemistry, vol. 208, no. 1, pp. 169-173, 1986.
[43] Y. Matsuo, "Ordered alloys in the cobalt-palladium system," Journal of the Physical Society of Japan, vol. 32, no. 4, pp. 972978, 1972.

[44] F. L. Williams and D. Nason, "Binary alloy surface compositions from bulk alloy thermodynamic data," Surface Science, vol. 45, no. 2, pp. 377-408, 1974.

[45] J. A. Abys, I. Boguslavsky, and H. K. Straschil, "Composition for electroplating plladium alloys and electroplating process using that composition," in US Patent, 1999.

[46] Y. Q. Zheng and H. Z. Xie, "Two malonato coordination polymers: syntheses and crystal structures of $\mathrm{M}\left(\mathrm{H}_{2} \mathrm{O}\right)_{2}\left(\mathrm{C}_{3} \mathrm{H}_{2} \mathrm{O}_{4}\right)$ with $\mathrm{M}=\mathrm{Co}$ and $\mathrm{Ni}, \mathrm{C}_{3} \mathrm{H}_{4} \mathrm{O}_{4}=$ malonic acid," Journal of Coordination Chemistry, vol. 57, no. 17-18, pp. 1537-1543, 2004.

[47] J. F. Moulder, W. F. Stickle, P. E. Sobol, and K. D. Bomben, Handbook of X-ray Photoelectron Spectroscopy, Physical Electronics, Eden Prairie, Minn, USA, 1992.

[48] T. Toda, H. Igarashi, and M. Watanabe, "Role of electronic property of Pt and Pt alloys on electrocatalytic reduction of oxygen," Journal of the Electrochemical Society, vol. 145, no. 12, pp. 4185-4188, 1998.

[49] T. Toda, H. Igarashi, and M. Watanabe, "Enhancement of the electrocatalytic $\mathrm{O}_{2}$ reduction on Pt-Fe alloys," Journal of Electroanalytical Chemistry, vol. 460, no. 1-2, pp. 258-262, 1999.

[50] J. P. Chevillot, J. Farcy, C. Hinnen, and A. Rousseau, "Electrochemical study of hydrogen interaction with palladium and platinum," Journal of Electroanalytical Chemistry, vol. 64, no. 1, pp. 39-62, 1975.

[51] J. F. Drillet, A. Ee, J. Friedemann, R. Kötz, B. Schnyder, and V. M. Schmidt, "Oxygen reduction at $\mathrm{Pt}$ and Pt70Ni30 in $\mathrm{H}_{2} \mathrm{SO}_{4} / \mathrm{CH}_{3} \mathrm{OH}$ solution," Electrochimica Acta, vol. 47 , no. 12, pp. 1983-1988, 2002.

[52] R. K. Raman, G. Murgia, and A. K. Shukla, "A solid-polymer electrolyte direct methanol fuel cell with a methanol-tolerant cathode and its mathematical modelling," Journal of Applied Electrochemistry, vol. 34, no. 10, pp. 1029-1038, 2004.

[53] Y. Suo, L. Zhuang, and J. Lu, "First-principles considerations in the design of Pd-alloy catalysts for oxygen reduction," Angewandte Chemie, vol. 46, no. 16, pp. 2862-2864, 2007.

[54] T. Biegler, D. A. J. Rand, and R. Woods, "Limiting oxygen coverage on platinized platinum; relevance to determination of real platinum area by hydrogen adsorption," Journal of Electroanalytical Chemistry, vol. 29, no. 2, pp. 269-277, 1971.

[55] S. Trasatti and A. Petrii, "Real surface area measurements in electrochemistry," Pure and Applied Chemistry, vol. 63, no. 5, pp. 711-734, 1991.

[56] H. Angerstein-Kozlowska, B. E. Conway, A. Hamelin, and L. Stoicoviciu, "Elementary steps of electrochemical oxidation of single-crystal planes of Au Part II. A chemical and structural basis of oxidation of the (111) plane," Journal of Electroanalytical Chemistry, vol. 228, no. 1-2, pp. 429-453, 1987.

[57] M. Baldauf and D. M. Kolb, "A hydrogen adsorption and absorption study with ultrathin Pd overlayers on $\mathrm{Au}(111)$ and Au(100)," Electrochimica Acta, vol. 38, no. 15, pp. 2145-2153, 1993.

[58] L. J. Wan, T. Suzuki, K. Sashikata, J. Okada, J. Inukai, and K. Itaya, "In situ scanning tunneling microscopy of adsorbed sulfate on well-defined $\operatorname{Pd}(111)$ in sulfuric acid solution," Journal of Electroanalytical Chemistry, vol. 484, no. 2, pp. 189193, 2000. 
[59] N. Hoshi, M. Kuroda, O. Koga, and Y. Hori, "Infrared reflection absorption spectroscopy of the sulfuric acid anion on low and high index planes of palladium," Journal of Physical Chemistry B, vol. 106, no. 35, pp. 9107-9113, 2002.

[60] S. Tominaka, T. Hayashi, Y. Nakamura, and T. Osaka, "Mesoporous PdCo sponge-like nanostructure synthesized by electrodeposition and dealloying for oxygen reduction reaction," Journal of Materials Chemistry, vol. 20, no. 34, pp. 7175-7182, 2010. 


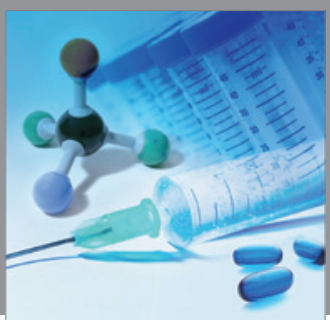

International Journal of

Medicinal Chemistry

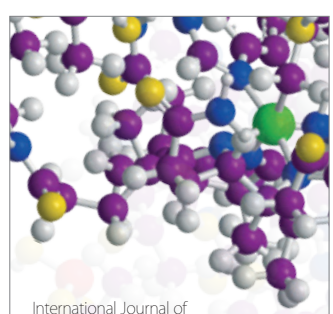

Carbohydrate Chemistry

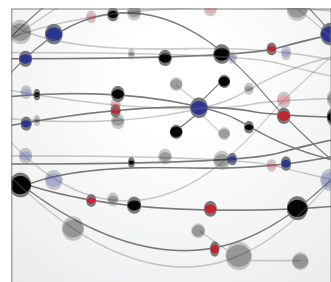

The Scientific World Journal
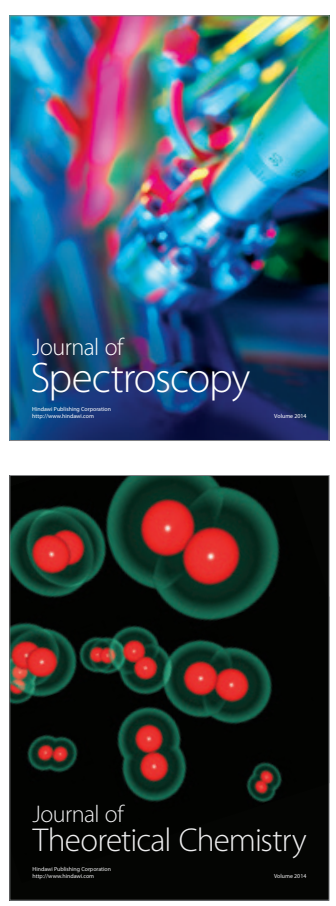
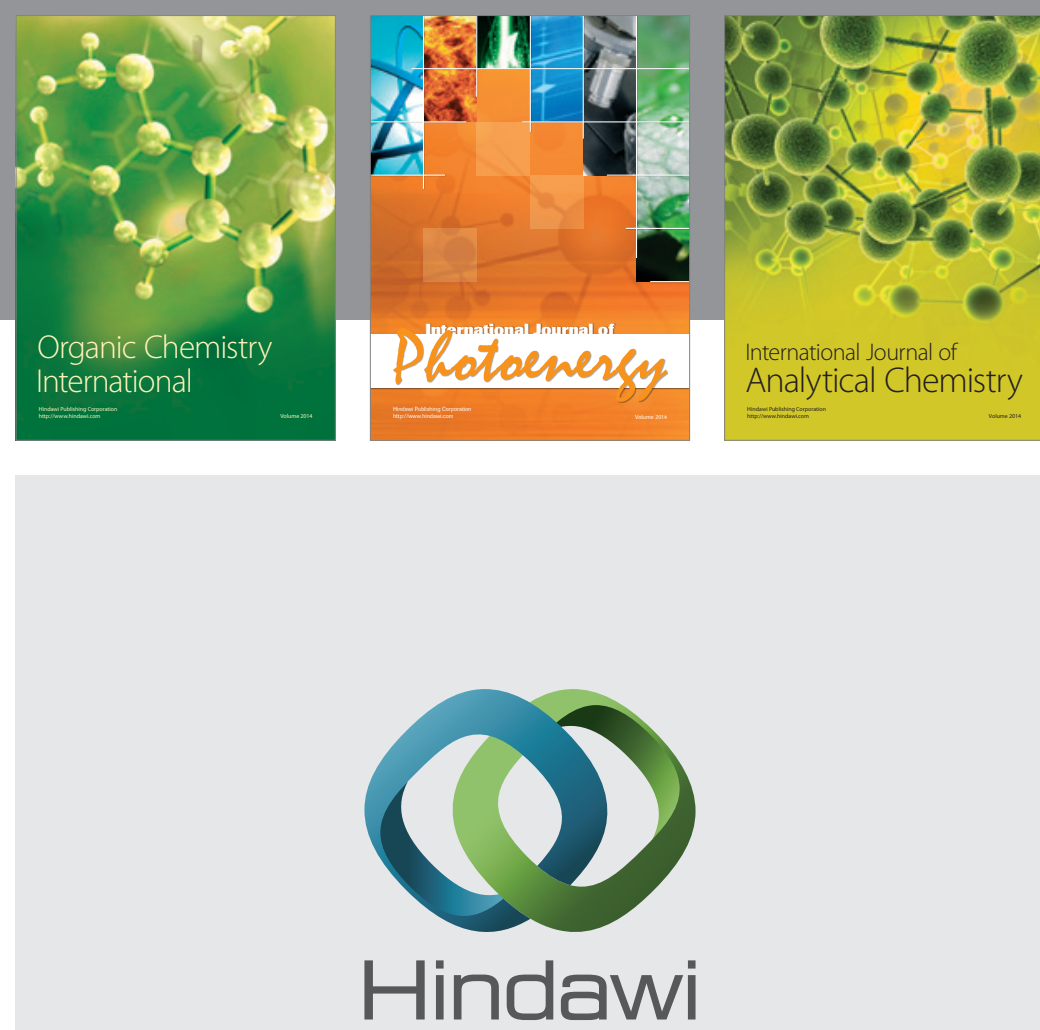

Submit your manuscripts at

http://www.hindawi.com
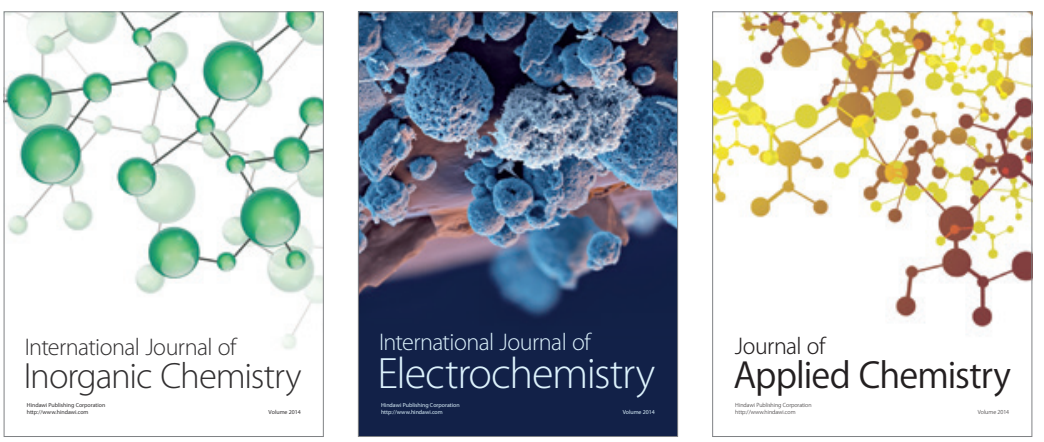

Journal of

Applied Chemistry
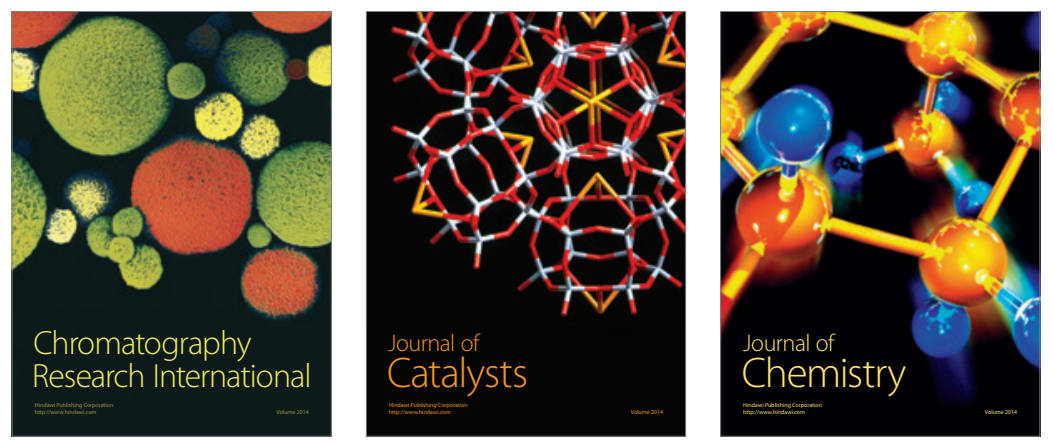
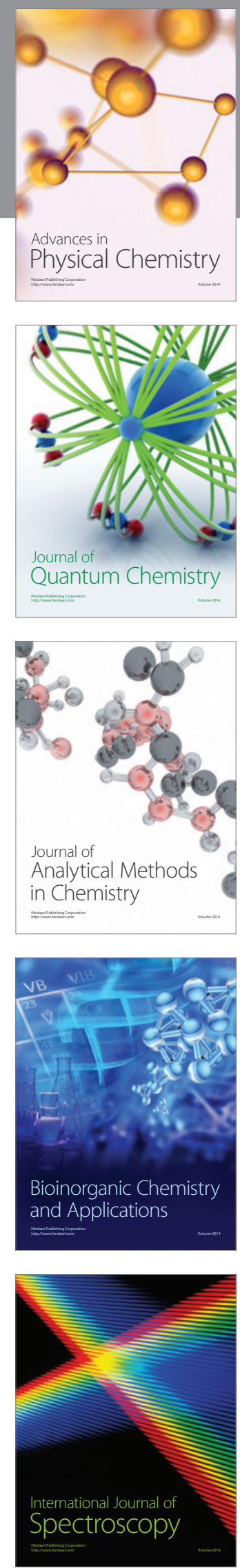